\title{
Entrepreneurial competences revised: developing a consolidated and categorized list of entrepreneurial competences
}

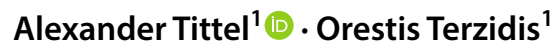

Received: 18 November 2019 / Revised: 18 November 2019 / Accepted: 23 December 2019 /

Published online: 3 February 2020

(c) The Author(s) 2020

\begin{abstract}
The goal of entrepreneurship education is to prepare students for entrepreneurial practice and to develop profound entrepreneurial competences. Due to the heterogeneity in definitions and competence frameworks in the field of entrepreneurship education, literature and practice still illustrate much confusion about what should be taught in academic entrepreneurship courses and which competences need to be developed. An in-depth review of entrepreneurial competences dates back to the year 2008 by Mitchtelmore and Rowley. The purpose of this paper is to review newer contributions and propose a synthesis of state-of-the-art by developing an updated entrepreneurial competence framework. Both, a consolidated categorization approach and a list of entrepreneurial competences are developed and suggested for educators for the development of academic courses and practice-oriented training programs.
\end{abstract}

Keywords Entrepreneurship education · Competence · Entrepreneurial competences $\cdot$ Systematic literature review

\section{Introduction}

The first entrepreneurship course at Harvard Business School was proposed by Myles Mace in 1947. Since then entrepreneurship has become an important academic and teaching field (Gartner and Vesper 1994; Katz 2003; Kuratko 2005). The fast-growing number of entrepreneurship courses worldwide led to a high variety of

Alexander Tittel

alexander.tittel@kit.edu

Orestis Terzidis

Orestis.terzidis@kit.edu

1 Institute for Entrepreneurship, Technology Management and Innovation, Karlsruhe Institute of Technology (KIT), Karlsruhe, Germany 
educational goals, teaching methods and evaluation approaches (Purzer et al. 2016; Samwel Mwasalwiba 2010)

Moreover, a harmonized definition of the term "Entrepreneurship Education" does not exist in the scientific community. In addition, enterprise education, entrepreneurship education, and entrepreneurial education are often used interchangeably (Samwel Mwasalwiba 2010). For this reason, Erkkilä (2000) has proposed a unifying term "entrepreneurial education" as encompassing both enterprise and entrepreneurship education.

Entrepreneurial education is "the process of providing individuals with the ability to recognize commercial opportunities and the insight, self-esteem, knowledge and skills to act on them" (Jones and English 2004, p. 416). Other authors still uphold the term "Entrepreneurship Education" and propose its goal as to prepare students for entrepreneurial practice and develop their knowledge, skills and attitudes (Garavan et al. 1994; Samwel Mwasalwiba 2010). It is interesting to note that according to the Recommendation of the European Parliament and the Council of 18 December 2006, knowledge, skills and attitudes are considered the key components of a competence (EU 2006, p. 13). In other words, entrepreneurship education aims to prepare students for entrepreneurial practice and develop entrepreneurial competences (Lackeus 2015).

As a result, due to the heterogeneity in definitions and approaches, literature and practice illustrate a certain confusion about what should be taught in academic entrepreneurship courses and which competences need to be developed.

The better educators are able to identify and determine qualification goals and learning objectives for entrepreneurship education, the better we can conceive and execute adequate pedagogical trainings. A key construct in pedagogy that can help educators to clarify and capture the learning objectives is the concept of competence. There are varying definitions and uses of the word "competence" in the context of pedagogy, entrepreneurship education and education policy. Therefore, a conceptual clarification is desirable. Also, it is essential to review which specific competences are considered to be important in entrepreneurship education in order to create a sound basis for the design and implementation of high-quality courses and programs. Clarity about entrepreneurial competences will support educators to choose content, define learning outcomes, develop instructional design and appropriate methods for monitoring and evaluation.

In fact, the discussion about entrepreneurial competences is not new. An indepth review dates back to the year 2008 by Mitchtelmore \& Rowley. The topic still attained attention after 2010, and quite a number of newer contributions have been published. This paper reviews these newer contributions and proposes a synthesis of state-of-the-art.

This article formulates four contributions: (1) It lists all definitions of "competence" and "entrepreneurial competence" found in the literature and shows overlaps and inconsistencies. (2) It suggests a consolidated definition of "entrepreneurial competence," consistent with prominent definitions in pedagogy, entrepreneurship literature and policy. (3) It creates a merged and consolidated list of all entrepreneurial competences found in the entrepreneurship literature. (4) It creates a category system for the list. 


\section{Methodology}

The study is a systematic literature review (SLR) and is based on the guidelines suggested by Kitchenham (2007). A SLR aims to systematically find primarily studies that are relevant for the research question by applying a transparent and unbiased search strategy (ibid).

The aim of the review is twofold. First, it aims to develop a comprehensive understanding of state-of-the-art in the entrepreneurship competence domain, and second, to identify, consolidate and structure the entrepreneurship-specific competences that are discussed in the literature.

\section{Research questions}

The research questions (RQ) and the corresponding sub-questions (SQ) addressed in the review are:

- RQ 1: Which definitions for "competence" can be found in the literature?

- RQ 2: Which definitions for "entrepreneurial competence" (EC) can be found in the literature?

- RQ 3: Which entrepreneurial competences are considered to be important in the literature?

As a large number of entrepreneurial competences are expected to be compiled from the literature, a potential categorization framework could help to structure and organize the competences in different categories. For that reason, the subquestion to RQ 1 is: What types of competences can be found in the literature (SQ 1.1)? With respect to RQ 2, three sub-questions are formulated: SQ 2.1: Who are the most cited authors concerning ECs in the last ten years? SQ 2.2: What are the most common definitions of an EC used by the authors? SQ 2.3. What types of EC can be found in the literature?

\section{Research process}

\section{Identification of literature}

For the identification of relevant research, we applied an iterative search strategy to find relevant literature and databases, test various combinations of key terms and assess the potentially relevant publications. The identification of literature with a focus on the different research questions required a divergent and convergent exploration approach. For that reason, with respect to different thematic foci of research, we adjusted the search strategy in the time frame and the scope of the search. Starting with the identification of definitions and the categorizations of 
Table 1 Selected databases for data collection

\begin{tabular}{lll}
\hline Database & Content & Link \\
\hline EconBiz & Economy & https://www.econbiz.de \\
ERIC & Pedagogy & https:/eric.ed.gov \\
Pedocs & Pedagogy & https://www.pedocs.de \\
Scopus & Multidisciplinary & https://www.scopus.com \\
Hogrefe & Psychology & https://econtent.hogrefe.com/psychology \\
Web of Science & Multidisciplinary & http://apps.webofknowledge.com \\
Google Scholar & Multidisciplinary & https://scholar.google.de \\
JRC Publications & Multidisciplinary & http://publications.jrc.ec.europa.eu \\
Cedefob & Multidisciplinary & http://www.cedefop.europa.eu/ \\
Tandfonline & Multidisciplinary & https://www.emeraldinsight.com/ \\
Springer Link & Multidisciplinary & https://link.springer.com \\
\hline
\end{tabular}

Table 2 Definition of search terms

\begin{tabular}{|c|c|c|}
\hline Key terms & Competence & Entrepreneurship \\
\hline Generic term & $\begin{array}{l}\text { Competence, competency, competencies, } \\
\text { competences }\end{array}$ & Entrepreneurship \\
\hline Subsumable terms & Skills, expertise, knowledge & Founder, entrepreneurial, entrepreneur \\
\hline Related terms & $\begin{array}{l}\text { Ability, abilities, capabilities, hard skills, } \\
\text { soft skills, know-how, qualification, } \\
\text { Capacity }\end{array}$ & Start-up, business, venture, enterprise \\
\hline Terms in German & Kompetenz, Qualifikation & Unternehmertum, Gründertum \\
\hline
\end{tabular}

competence, the time frame and the domain were not restricted (divergent search on competence from pedagogical and education policy perspective).

As mentioned above, a valid review of entrepreneurial competences appeared by Mitchelmore and Rowley in 2010, who had looked at publications until 2008. For that reason, we limited the search of EC literature to the last decade from 2008 to 2018. However, during the research process and the content analysis, we identified publications from authors outside the time frame and included them to address the specific research and sub-questions.

As a result, the search process was conducted manually by searching the search engines in the scientific and policy databases on entrepreneurship, pedagogy and social sciences. The databases are given in Table 1.

For the identification of appropriate search terms, a thesaurus was used to include generic, subsumable and related terms of the key terms "competence" and "entrepreneurship." Table 2 illustrates the search terms that were initially used for data collection.

First, a search was conducted with the single term "competence" to prove the availability of studies with the research objective. To reduce the high number of initial results and restrict the search field on the conceptualization and definition of 
the term competence, the keywords "framework" and "concept" were added to the search term (search string 1). Subsequently, the search string 2 was applied with respect to entrepreneurial competence. The following search strings articulate the final search logic that was applied in the study to find relevant literature for definition and conceptualization of competence (1) and entrepreneurial competence (2):

1. Kompetenz OR Competenc* AND (Framework OR Concept)

2. (Entrepreneur* AND competenc*) OR Unternehmer* AND Kompetenz

The search strings include the following variations of the German and English terms: (a) Competence, competences, competency, competencies; (b) Entrepreneur: entrepreneurship, entrepreneur, entrepreneurial; and (c) Unternehmer, Unternehmertum, unternehmerische.

The search strings were slightly modified to meet the specific configuration requirements for each database.

\section{Study selection strategy}

An in-depth understanding of the conceptualization of EC requires the analysis of the state-of-the-art of the concept of competence in its origins. Thus, a search was conducted to identify relevant articles for the definitions and conceptualizations of the term competence in interdisciplinary, pedagogic, and policy databases: Pedocs, ERIC, JRC and Google Scholar. Due to the tremendous number of initial hits (over 3 mill.), the following inclusion criteria were applied:

- Explicit definition of competence.

- Peer reviewed article.

- Official policy paper.

- Concept of competence as a central issue in the article or book.

Next, we applied the search and selection strategy for literature on EC shown in Fig. 1. The main objective was to identify studies that fulfill the following inclusion criteria:

- Published between 2008 and 2018.

- Includes a definition of EC.

- Includes a list of ECs.

The initial search for EC included the related, subsumable and translated terms (see Table 2) and generated over 4400 hits with different degree of relevance for the study. After a first selective revision of articles and identification of the existing cases, it emerged that most studies were not relevant for our research questions. In particular, the related terms produced a high number of articles that were out of scope dealing, for instance, with agriculture, accounting or banking. These terms were excluded in the revised search string. Sources that were not accessible 


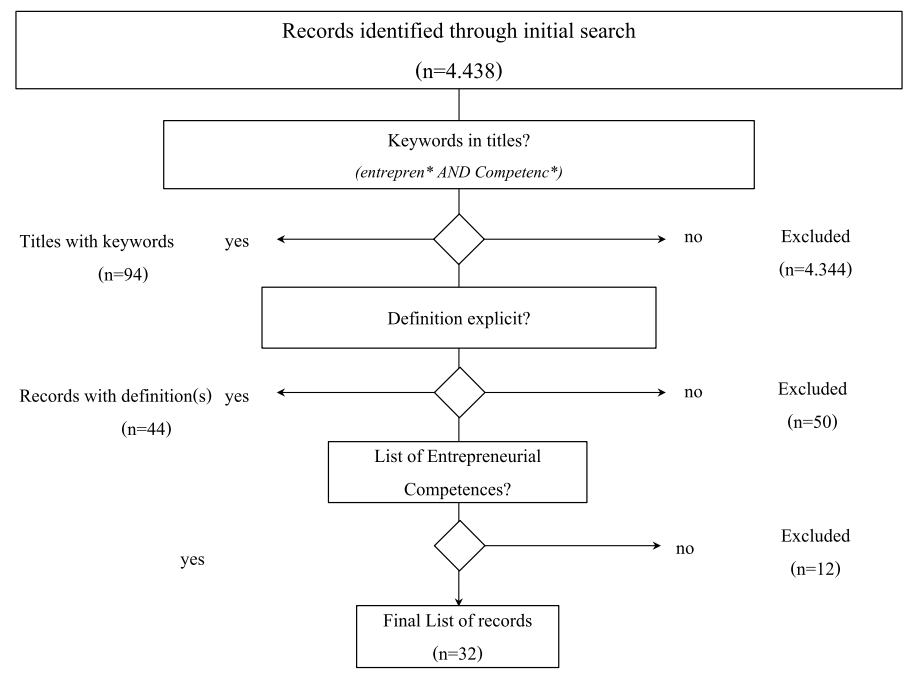

Fig. 1 Literature search and selection strategy for entrepreneurial competence

through databases or not obtainable online or in local libraries were also excluded from the list. Systematic literature reviews, research articles, books, and working papers dealing with entrepreneurial competences were included in the final list.

\section{Results}

As a result, 38 key articles on the concept of competence and 32 papers that include both a definition of EC and a list of ECs were identified. A final list of the selected research on EC is given in Table 3. In this section, the search results are presented. A discussion and a conceptual synthesis of the respective findings can be found in "Discussion and conceptual synthesis" section.

\section{Definitions of competence}

With respect to RQ 1, 12 definitions of competence were identified and are given in Table 4. To present a panoramic view on the concept, we identified well-established and recognized definitions on policy level in the European Union, the USA, Germany, as well as other prominent sources in education science (Weinert 2001) as well as occupational, pedagogical and psychological perspective (Erpenbeck and Von Rosenstiel 2011). On first sight, the authors use different approaches, terms, and components to define "competence." A closer look however reveals a shared understanding of the concept which is discussed in "Discussion and conceptual synthesis" section. 
Table 3 Final list of literature on entrepreneurial competences

\begin{tabular}{|c|c|c|c|}
\hline Nr. & Author & Entrepreneurial & Country \\
\hline 1 & Ahmad et al. (2010) & Competency & Malaysia \\
\hline 2 & Ahmad et al. (2018) & Competencies & Malaysia \\
\hline 3 & Anis at al. (2016) & Competencies & Malaysia \\
\hline 4 & Bikse and Riemere (2013) & Competences & Latvia \\
\hline 5 & Bortkevi (2015) & Competence & Not specified \\
\hline 6 & Bortkevi at al. (2016) & Competence & Lithuania \\
\hline 7 & Zarefard and Beri (2017) & Competencies & Iran \\
\hline 8 & Edwards-Schachter et al. (2015) & Competences & Not specified \\
\hline 9 & Gümüsay and Bohné (2018) & Competencies & Not specified \\
\hline 10 & Ismail (2014) & Competency & Indonesia \\
\hline 11 & Ismail and Efendy (2015) & Competence & Indonesia \\
\hline 12 & Jamin et al. (2016) & Competencies & Malaysia \\
\hline 13 & Kabir et al. (2017) & Competencies & Nigeria \\
\hline 14 & Khalid and Khalid (2015) & Competencies & Not specified \\
\hline 15 & Komarkova et al. (2015) & Competence & Europe \\
\hline 16 & Kyndt and Herman (2015) & Competencies & Belgium \\
\hline 17 & Mets et al. (2017) & Competences & Estonia \\
\hline 18 & Mitchelmore and Rowley (2010) & Competencies & Not specified \\
\hline 19 & Mitchelmore and Rowley (2013) & Competencies & England/Wales \\
\hline 20 & Muzychenko (2008) & Competence & Europe \\
\hline 21 & Ahmad et al. (2018) & Competencies & Malaysia \\
\hline 22 & Peltonen (2015) & Competences & Europe \\
\hline 23 & Penchev and Salopaju (2011) & Competencies & Sweden \\
\hline 24 & Phelan and Sharpley (2012) & Competencies & England \\
\hline 25 & Rasmussen and Wright (2015) & Competency & Not specified \\
\hline 26 & Rasmussen et al. (2011) & Competencies & UK/ Norway \\
\hline 27 & RezaeiZadeh et al. (2017) & Competencies & Ireland/ Iran \\
\hline 28 & Sanchez (2012) & Competencies & Spain \\
\hline 29 & Schelfhout et al. (2016) & Competence & Not specified \\
\hline 30 & Sentosa and Ariusni (2017) & Competency & Indonesia \\
\hline 31 & Tehseen and Ramayah (2015) & Competencies & Malaysia \\
\hline 32 & Trivedi et al. (2009) & Competence & India \\
\hline
\end{tabular}

\section{Categories of competence}

Five approaches with 14 different categories of competence were identified and are given in Table 5. Four of the five sources are policy sources from the European Union (EU Council), Germany (German Qualification Framework DQR, The Standing Conference of the Ministers of Education and Cultural Affairs KMK), and the USA (National Research Council). Moreover, the study includes the handbook for competence assessment from the occupational, pedagogical, and psychological 
Table 4 Definitions of competence

Source Definition

EU Parliament and the Council (2006, p. 13)

Competence is a combination of knowledge, skills and attitudes appropriate to the context.

ERIC (2019, online)

The individual's demonstrated capacity to perform, i.e., the possession of knowledge, skills and personal characteristics needed to satisfy the special demands or requirements of a particular situation

BIBB (2018, online)

DQR (2011, p. 17)

Lokhoff et al. (2010, p. 21)

Erpenbeck and von Rosenstiel (2011, p. 24)

Weinert (2001, p. 27)

Klieme and Leutner (2006, p. 879)

$\operatorname{DeSeCo}(2001$, p. 13)

Dominique Simone Rychen (2002, p. 5)

Beaumont (1995, p. 12)

Competence is understood as the combination of knowledge and skills in coping with the requirements of action (translated)

Competence describes the ability and readiness of the individual to use knowledge, skills and personal, social and methodological competences and to behave in a considered, individual and socially responsible manner. Competence is understood in this sense as comprehensive action skills

Competence is a quality, ability, capacity or skill that is developed by and that belongs to the student

Competences are considered as dispositions of selforganized behavior

Competences are understood as cognitive abilities and skills possessed by or able to be learned by individuals that enable them to solve particular problems, as well as the motivational, volitional and social readiness and capacity to utilize the solutions successfully and responsibly in variable situations [translated by Klieme and Leutner (2006, p. 309)]

Context-specific cognitive dispositions that are acquired by learning and needed to successfully cope with certain situations or tasks in specific domain

For the Swedish Metal Workers' Union, a competence is a combination of what one knows, what one can do, what one wants, and what one dares to do. "Know" means theoretical knowledge, "can" implies practical knowledge and informal knowledge, "want" deals with ambition, attitude, goals and outlook, and "dare" reflects self-confidence and self-esteem

A competence is the ability to meet a complex demand successfully or carry out a complex activity or task

The ability to apply knowledge, understanding and skills in performing to the standards required in employment. This includes solving problems and meeting changing demands'

Mulder (2007, p. 11)

In an educational context, competence is the general capability of persons (or organisations) to perform (such as an activity, a task, solve a problem) that is developing, and if a program is successfully completed, the candidate receives a license 
Table 5 Categorization approaches of competence

\begin{tabular}{|c|c|}
\hline Source & Categorization of competence \\
\hline EU $(2005$, p. 11) & $\begin{array}{l}\text { Cognitive competence } \\
\text { Functional competence } \\
\text { Personal competence } \\
\text { Ethical competence }\end{array}$ \\
\hline DQR (2011, p. 16) & $\begin{array}{l}\text { Professional competence } \\
\text { Personal competence } \\
\text { Learning competence } \\
\text { Methodological competence } \\
\text { Social competence }\end{array}$ \\
\hline National Research Council (2012, p. 3) & $\begin{array}{l}\text { The cognitive domain } \\
\text { The intrapersonal domain } \\
\text { The interpersonal domain }\end{array}$ \\
\hline KMK (2011, p. 14) & $\begin{array}{l}\text { Action competence } \\
\text { Professional competence } \\
\text { Self-competence } \\
\text { Social competence } \\
\text { Method competence } \\
\text { Communication competence } \\
\text { Learning competence }\end{array}$ \\
\hline Erpenbeck and von Rosenstiel (2011, p. 24) & $\begin{array}{l}\text { Personal competence } \\
\text { Action competence } \\
\text { Professional-methodological competence } \\
\text { Social-communicative competence }\end{array}$ \\
\hline
\end{tabular}

perspective (Erpenbeck and Von Rosenstiel 2011). The categories given in Table 5 provide the first indication of potential competence areas. They can be condensed into three main categories: personal competence, social competence and domain competence.

\section{Definitions of entrepreneurial competence}

To address RQ 2 and the related sub-questions, we identified 33 articles (Table 3 ) that primarily deal with entrepreneurial competences, present explicit definitions and list competences that are relevant for entrepreneurship (inclusion criteria). In most cases, the authors cited other sources for the definition and specification of ECs. With respect to SQ 2.1 and SQ 2.2, a citation network (Fig. 2) was developed using the igraph package in $\mathrm{R}$. The network diagram depicts citation network of authors in the research field of ECs. The size of the knots indicates the frequency of definition citations of EC by other authors. As a result, Fig. 2 illustrates that the authors Bird (1995), Man et al. (2002) and Mitchelmore and Rowley (2010) are indicated as the most cited authors when introducing and defining the term "Entrepreneurial Competence." The respective 


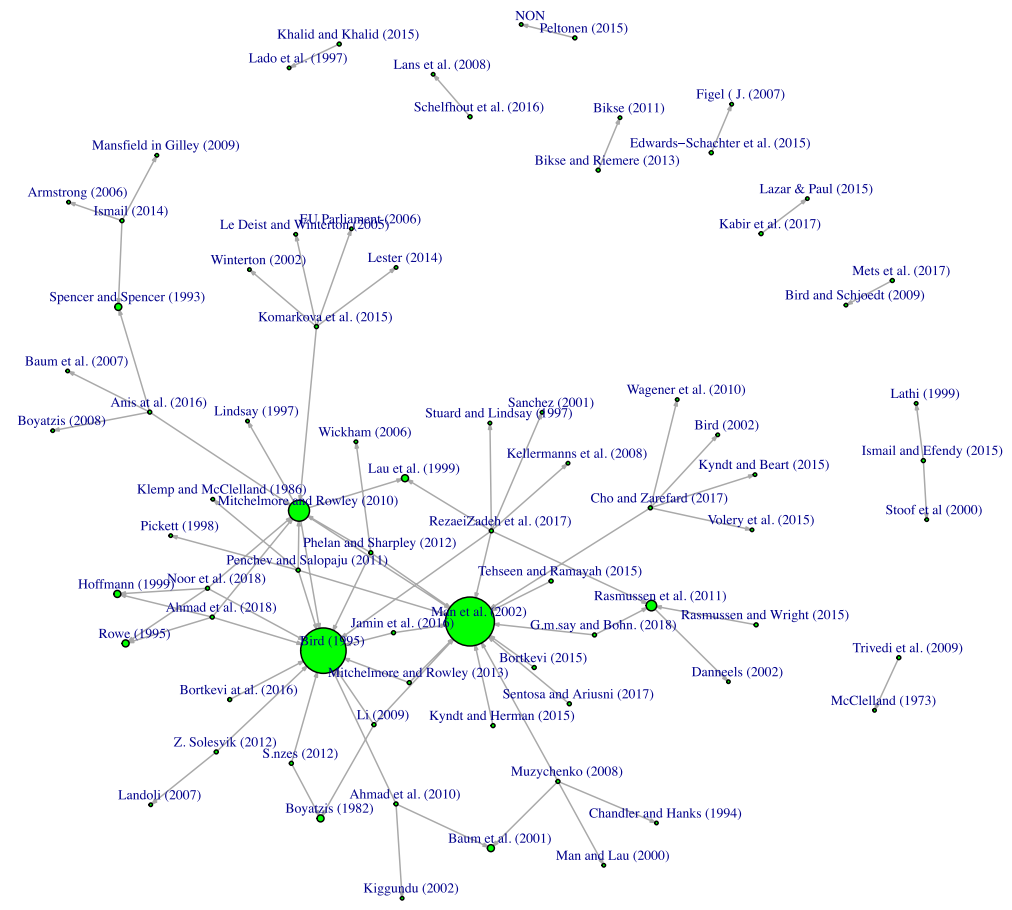

Fig. 2 Citation network: definitions of entrepreneurial competence

definitions of the key authors and the number of their citations are given in Table 6 . Moreover, we identified these authors to be of vital importance not only with regard to the definitions but also for categorization and the listing of ECs.

\section{Categories of entrepreneurial competence}

With respect to the categorization of ECs (SQ 2.3), we identified seven authors with 22 different categories. The categorization approaches of ECs used by the authors are given in Table 7. Moreover, the search was extended to find entrepreneurship-related categories and to prove if they could be used for an appropriate ECs categorization framework (see Table 8). For instance, the phases of venture development and the processes might serve as an inspiration or even as an appropriate categorization approach. We also considered the key activities and components of a venture by integrating the nine building blocks of the prominent business model canvas (Osterwalder and Pigneur 2010).

\section{Entrepreneurial competences discussed in the literature}

With respect to RQ 3, we compiled a list with 376 ECs (long list) mentioned and discussed in the entrepreneurship literature. Following the procedure in "Definitions 


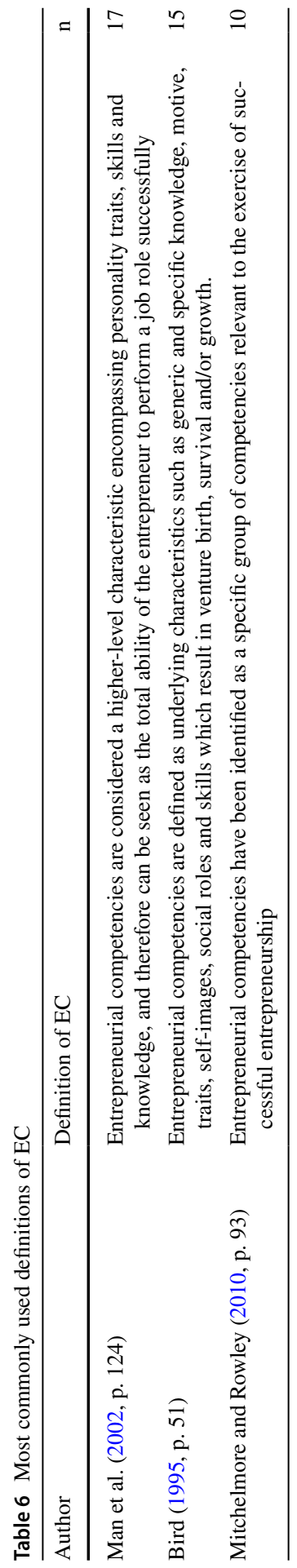


Table 7 Categories of entrepreneurial competences

\begin{tabular}{|c|c|}
\hline Author & Categorization of EC \\
\hline Man et al. (2002) & $\begin{array}{l}\text { Opportunity competences } \\
\text { Relationship competences } \\
\text { Conceptual competences } \\
\text { Organizing competences } \\
\text { Strategic competences } \\
\text { Commitment competences }\end{array}$ \\
\hline Schallenkamp and Smith (2008) & $\begin{array}{l}\text { Technical skills } \\
\text { Managerial skills } \\
\text { Entrepreneurial skills } \\
\text { Personal maturity skills }\end{array}$ \\
\hline Mitchelmore and Rowley (2010) & $\begin{array}{l}\text { Business and management competencies } \\
\text { Human relations competencies } \\
\text { Entrepreneurial competencies } \\
\text { Conceptual and relationship competencies }\end{array}$ \\
\hline Komarkova et al. (2015) & $\begin{array}{l}\text { Operational and contextual } \\
\text { Entrepreneurial } \\
\text { Conceptual and relationship }\end{array}$ \\
\hline Lackeus (2015) & $\begin{array}{l}\text { Knowledge } \\
\text { Skills } \\
\text { Attitude }\end{array}$ \\
\hline Bacigalupo et al. (2016) & $\begin{array}{l}\text { Into action } \\
\text { Resources } \\
\text { Ideas and opportunities }\end{array}$ \\
\hline Bird (1995) & $\begin{array}{l}\text { Motive and trait level } \\
\text { Social role and self concept level } \\
\text { Skill level }\end{array}$ \\
\hline
\end{tabular}

of entrepreneurial competence" section, we wanted to identify the most prominent sources with a well-established and recognized list of ECs. Unfortunately, a citation network could not provide much clarity as the citations are widely scattered. This fact shows another lack of consensus and clarity in the entrepreneurship community. A citation cluster as we find it in the definitions of EC could not be identified. Thus it can be stated that a consistent and generally accepted source for ECs does not exist in the scientific entrepreneurship literature.

Upon closer inspection, moreover, we identified an apparent ontological inconsistency in the lists of ECs. Many authors present not only ECs in the narrow sense but a mix of competences, skills, traits and other constructs that are relevant for entrepreneurial action. To consolidate the list, we applied the selection strategy illustrated in Fig. 3. First, we eliminated the duplicates from the long list using a spreadsheet software. Subsequently, we identified synonyms (negotiations, negotiating, negotiate) reducing the list to 108 items. After the 
Table 8 Entrepreneurship-related categories

\begin{tabular}{|c|c|c|}
\hline Author & Categorization & View \\
\hline Gartner (1985) & $\begin{array}{l}\text { Individuals } \\
\text { Organization } \\
\text { Process } \\
\text { Environment }\end{array}$ & Framework for new venture creation \\
\hline Glasl and Lievegoed (1993) & $\begin{array}{l}\text { Pioneer } \\
\text { Differentiation } \\
\text { Integration } \\
\text { Association }\end{array}$ & Phases \\
\hline Chell and Athayde (2009) & $\begin{array}{l}\text { Ideation } \\
\text { Opportunity recognition } \\
\text { Opportunity formation } \\
\text { Opportunity exploitation }\end{array}$ & Process \\
\hline Moberg et al (2014) & $\begin{array}{l}\text { Exploration } \\
\text { Evaluation } \\
\text { Exploitation }\end{array}$ & Process \\
\hline Hayton and Kelley (2006) & $\begin{array}{l}\text { Innovating } \\
\text { Brokering } \\
\text { Championing } \\
\text { Sponsoring }\end{array}$ & Entrepreneurial roles \\
\hline Osterwalder (2010) & $\begin{array}{l}\text { Value proposition } \\
\text { Customer segments } \\
\text { Channels } \\
\text { Relationship } \\
\text { Key partners } \\
\text { Key resources } \\
\text { Key activities } \\
\text { Cost structure } \\
\text { Revenue streams }\end{array}$ & Framework for new venture creation \\
\hline Vesper (1990) & $\begin{array}{l}\text { Business opportunity } \\
\text { Technical know-how } \\
\text { Business know-how } \\
\text { Entrepreneurial initiative }\end{array}$ & Elements in venture creation process \\
\hline
\end{tabular}

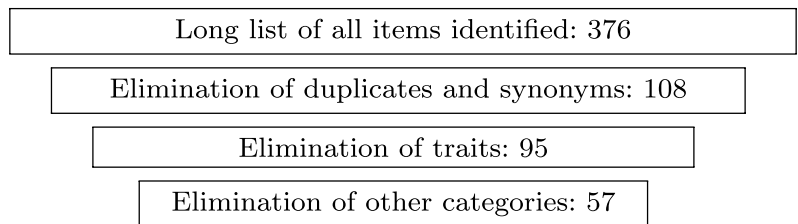

Fig. 3 Algorithm for selection of ECs 
elimination of traits, the record still included other psychological constructs such as abilities, awareness and attitudes that we compiled in the column "other categories." As a result, we developed a consolidated list of ECs from all 32 literature sources identified by this study, including 57 ECs. Moreover, analyzing the ontology of the terms, we identified and classified the items in three categories: entrepreneurial competence, personal traits and other categories. To ensure the validity and completeness of the final list, we revisited the collection of other prominent authors in the field of EC and confirmed the representation of our list. For that reason, we identified the authors Mitchelmore and Rowley (2010), Komarkova et al. (2015), Man et al. (2002), and Chandler and Jansen (1992) as four important authors in our list as they represent research work on ECs from different decades. Moreover, the lists of Mitchelmore and Rowley (2010) and (2015) are generated through in-depth former literature analysis and a desk review. Man et al. (2002) examined previous empirical studies in ECs and presented six competence areas with a short definition of behavioral focus. Chandler and Jansen (1992), on the other hand, surveyed with founders in different types of businesses and provided a list of self-perceived ECs (p. 228).

To consolidate the EC list of the four authors with 126 items in total, we also applied the algorithm by eliminating the duplicates and synonyms, traits and other constructs reducing the list to 32 competences. Based on that we compared our list with those of the authors ensuring and confirming that all 32 items are included in our final list.

The final list of ECs including personal traits and other categories is presented in Table 9.

\section{Discussion and conceptual synthesis}

As stated above, the goal of entrepreneurship education is to prepare students for entrepreneurial practice, which implies the development of entrepreneurial competences. In order to develop an appropriate education and training program for future entrepreneurs, educators first need a clear understanding of the meaning of the concept to be able to operationalize the development and evaluation of competence in their academic settings. For that reason, we first conduct a critical analysis of the terms "competence" and "entrepreneurial competence" in order to decompose the concepts into their components and determine a clear definition of both terms. Next, we review and discuss the categorization approaches of competence and EC in order to develop a framework for ECs. Furthermore, in their systematic literature review, Mitchelmore and Rowley (2010, p. 93) describe EC as a "specific group of competencies relevant to the exercise of successful entrepreneurship." Unfortunately, the question remains open what exactly is the "specific group" and which competences does it include? For that reason, we condense the ECs mentioned in the literature and develop a consolidated list of ECs. 


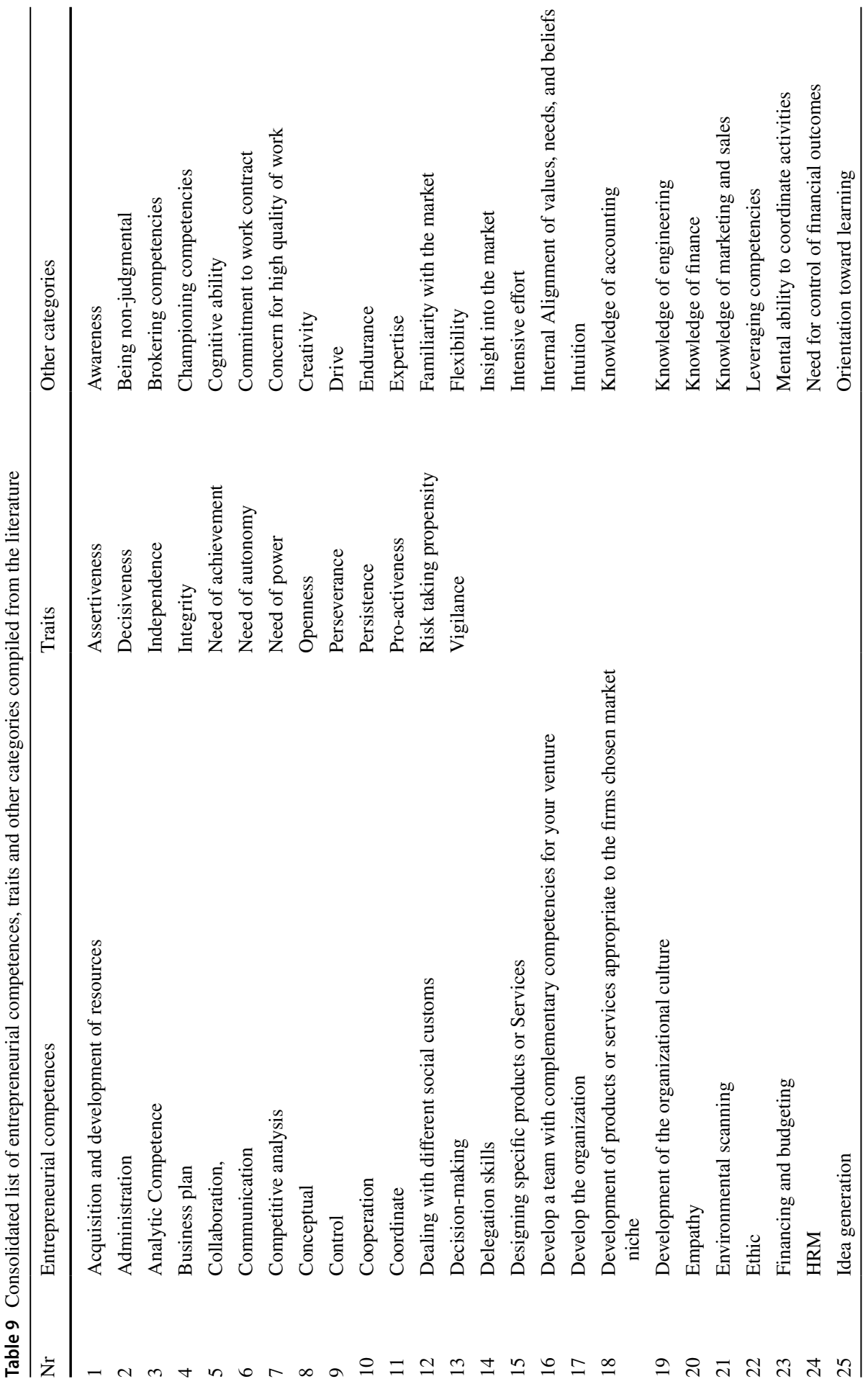




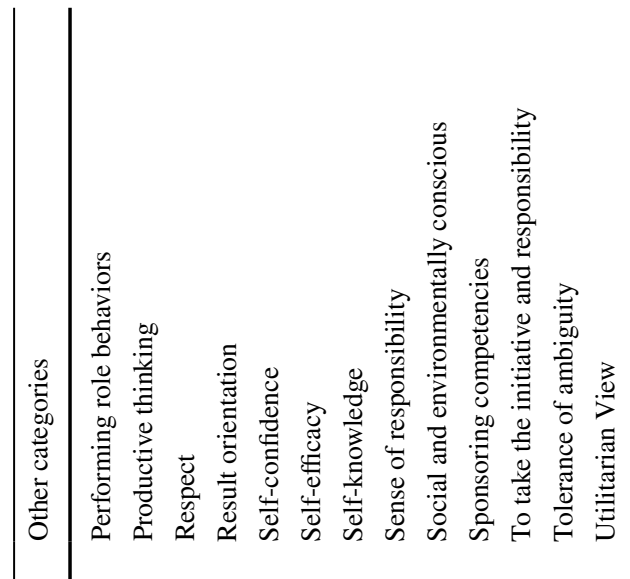

营 


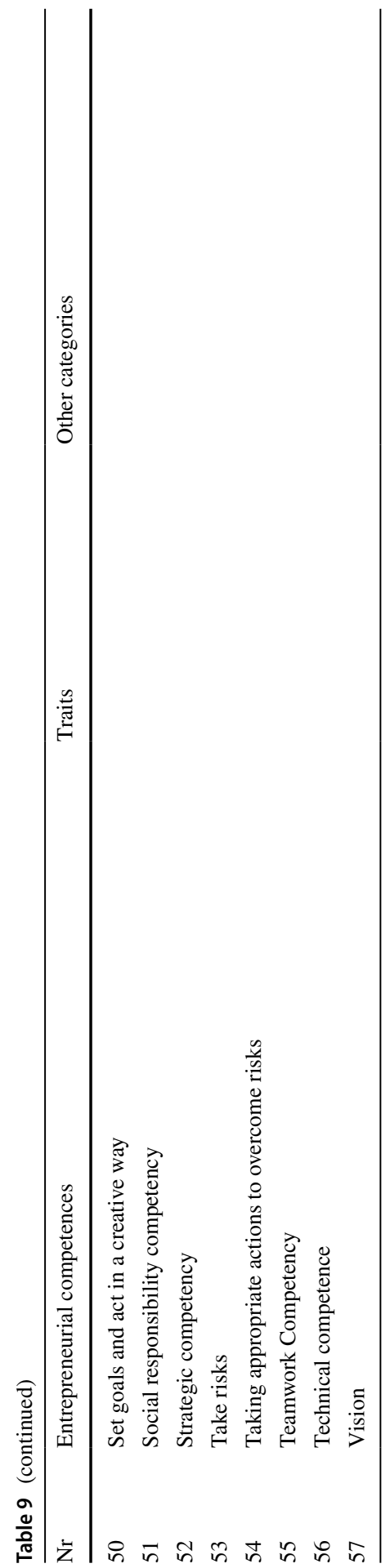




\section{Clarification and organization of competence}

The search strategy in our research provided the identification of 12 different definitions of competence (Table 4). However, in his study on competence development in organizations, Mulder (2002) found and compared over 40 different definitions of this term. It is a remarkable fact that the term is used neither uniformly nor always appropriately in the literature (Bunk 1994). Moreover, the term is associated with different traditions in different countries and is underpinned by contrasting motivations for use in different fields, such as Human Resource Development as well as Vocational Education and Training (Sultana 2009). As a result, the attempts to establish a consistent terminology of competence had a little impact today (Deist and Winterton 2005). In order to fully understand and classify the various concepts of entrepreneurial competence, challenges, and also its implications for the development of entrepreneurship education, an in-depth understanding of competence is needed. Comprehensive in-depth analysis of the competence debate can be found in the work of Deist and Winterton (2005), Mulder (2007), Schaper et al. (2012) and Sultana (2009). Based on different perspectives depicted by the authors, we give a thematic overview and classification of the competence debate and present its different approaches and views.

The development of competence approaches in different regions and contexts was triggered by a fast pace of economic change and globalized competition in the markets. The socioeconomic challenges, therefore, required a long-term strategy and renewed the popularity of competence-based approaches in education and training systems (Sultana 2009). With its long history, many facets of competence have been developed in various contexts (geographically, domain, and context-specific).

As one of the first authors, White (1959) is credited for the introduction of the term competence to describe personality characteristics associated with superior performance and high motivation (Deist and Winterton 2005). Later in the early 1970s, researchers and practitioners were concerned about the extensive measures of personality traits, skills, intelligence, and attitudes to identify and develop successful and effective leaders and company managers. Unfortunately, these tests turned out to be poor predictors of job performance and critical for validation. However, in particular, in the zeitgeist of intelligence tests, McClelland (1973) introduced the concept of competence for prediction of personal success. With this background, competence approaches initially focused on performance at the expense of complex intellectual processes and reflection in and on action (Sultana 2009). Different practice-oriented competence approaches (see work of Boyatzis 1982; Schroder 1989; Spencer 1983) evolved to identify, develop and assess the capabilities of managers that were later adopted and refined in other fields, such as Vocational Education and Training (VET) in the USA, Australia and Europe.

In the context of business management and administration, the resource-based view (RBV) (Barney 1991; Barney and Arikan 2001) became an influential economic theory. The RBV emphasizes the internal core resources (i.e., internal competences) of the firm being of vital importance to gain a competitive advantage in globalized and highly competitive markets. Moreover, core competences were 
understood as being at the root of core products (Mulder 2007; Prahalad and Hamel 1990).

As stated above, there is a high variety of meanings and definitions of competence. This fact makes competence an unclear and "fuzzy concept" (Deist and Winterton 2005, p. 29). The term "competence" is interpreted and defined in terms of its meaning very differently depending on the specific context of use. Primarily, competence is used to describe the abilities and dispositions to cope with contextspecific requirements (Schaper et al. 2012, p. 12). Mulder (2007) identifies four categories of contexts in which competence can be used: Institutional, jurisdictional, organizational and personal. Consequently, the concept can be used in this context for accreditation, appropriateness, approval, authorization, certification, entitlement, jurisdiction, license, responsibility, qualification and right (ibid, p. 7).

Based on the discussion and definitions in Table 4, we consider competence as

the disposition to generate adequate actions to responsibly solve problems in variable situations. This ability is based on knowledge, skills and attitudes.

\section{Categories of competence}

In this section, we analyze the existing categories of competence compiled in Table 5 to give a summary of existing approaches and to develop an appropriate categorization approach that can be used for the concept of competence and subsequently entrepreneurial competence.

The Oxford Dictionary ${ }^{1}$ defines a category as a "class or division of people or things regarded as having particular shared characteristics." Moreover, in philosophy, a category is defined as "Each of a possibly exhaustive set of classes among which all things might be distributed" (ibid).

The original work on the process and rules of classification can be found in Bailey (1994). According to (Bailey 1994, p. 1) classification is defined as "the ordering of entities into groups or classes on the basis of their similarity." He discusses the role of taxonomies and typologies in social science and presents the following advantages of classification:

- Description of types.

- Reduction of Complexity.

- Identification of similarities of cases.

- Identification of differences of cases.

- Presenting an exhaustive list of dimensions.

- Comparison of types.

- The inventory and management of types.

- The study of relationships.

- Types as criteria for measurement.

- Versatility.

${ }^{1}$ Online: www.lexico.com/en. Retrieved: 12.06.2019. 
One of the purposes of the study is to create a consolidated and classified list of ECs that can be used as a scientific foundation for the development of competence-oriented entrepreneurship courses. In addition to the advantages of classification stated above, the classification framework of entrepreneurial competences (CFEC) needs to fulfill the following requirements and be applicable under conditions stated below:

- Target Groups Students with a technical engineering background, entrepreneurs, coaches, people responsible for intrapreneurship programs and accelerator programs in established companies and entrepreneurship support organizations.

- Objective of the CFEC Portray the specific characteristics of competences needed in entrepreneurship domain and classify them in meaningful clusters. Develop a comprehensive understanding of the ECs and can classify the ECs into appropriate categories. Develop a clear understanding of the difference between the concept of competence, traits and other concepts that are related to the entrepreneurship but are explicitly not competences according to the standard definitions of competence.

- Application fields of the CFEC Entrepreneurship courses and lectures, accelerator programs, innovation projects within and outside established companies to compare, reflect on and develop ECs in own contexts.

In this study, five established approaches with 14 categories of competence were identified and are presented in Table 5. It emerges that the categories can be semantically grouped on three levels: personal level (self- or personal competence and learning competence), social level (interpersonal domain and social-communicative competence) and professional/domain level (functional competence, professional and method competence). Table 10 presents prominent definitions of the categories. Based on that it can be summarized that the common sense of the definition of personal competence implies a person's disposition to act reflexively self-organized and in a responsible manner to develop and reach personal goals in different contexts.

Social competence is also described as an interpersonal competence. It refers to appropriate actions and responsible behavior in a social context such as communication, cooperation, problem solving and leadership.

Domain (also professional) competence is described as the disposition of a person to act and solve domain-specific tasks and problems by using appropriate methods, and domain-specific knowledge and skills. Domain competence is seen as the generic, integrated and internalized disposition to deliver sustainable effective performance (including realizing innovation, and creating transformation) in a certain professional domain, job, role, organizational context and task situation (Mulder 2014, p. 3).

Based on the categorizations and their definitions identified in this study, we suggest the following three categorizations and definitions for competence: 


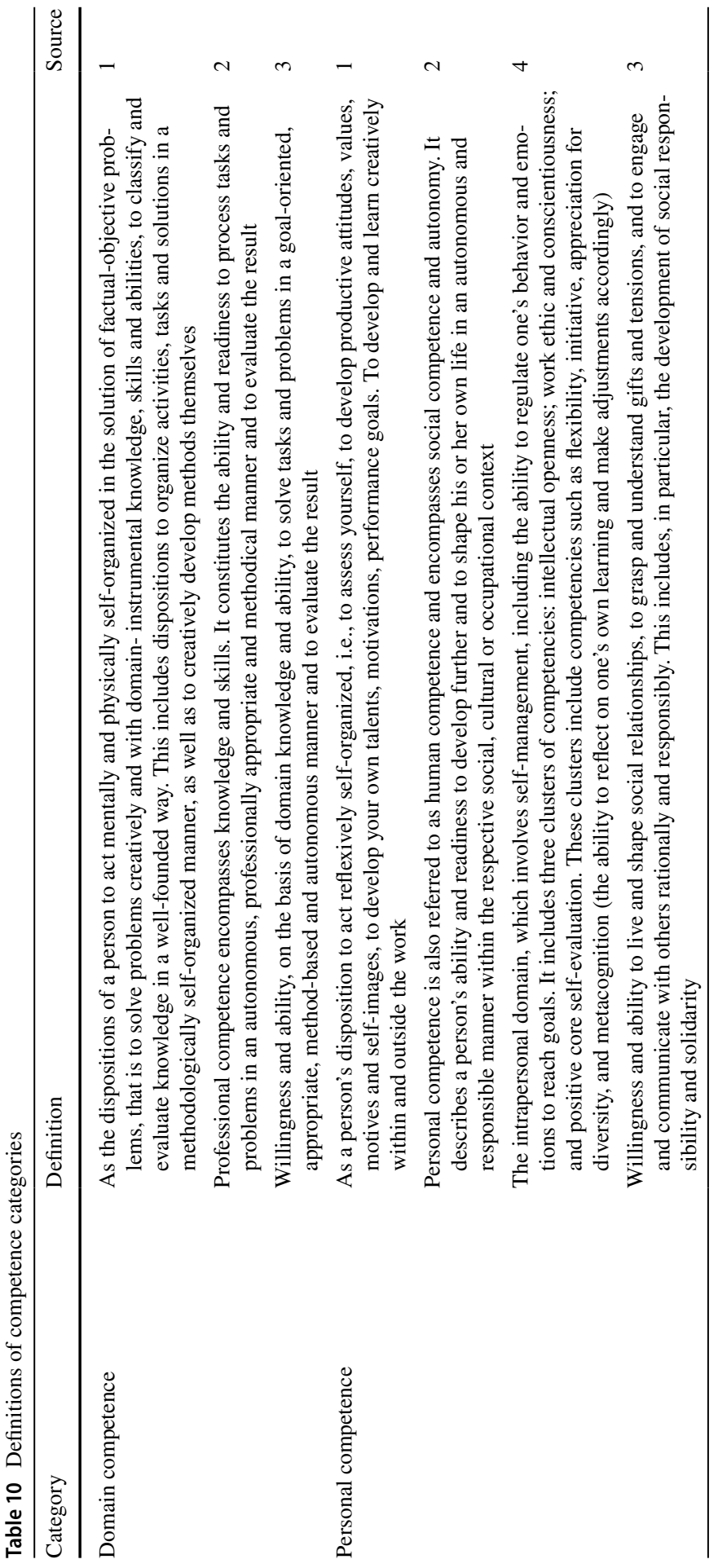




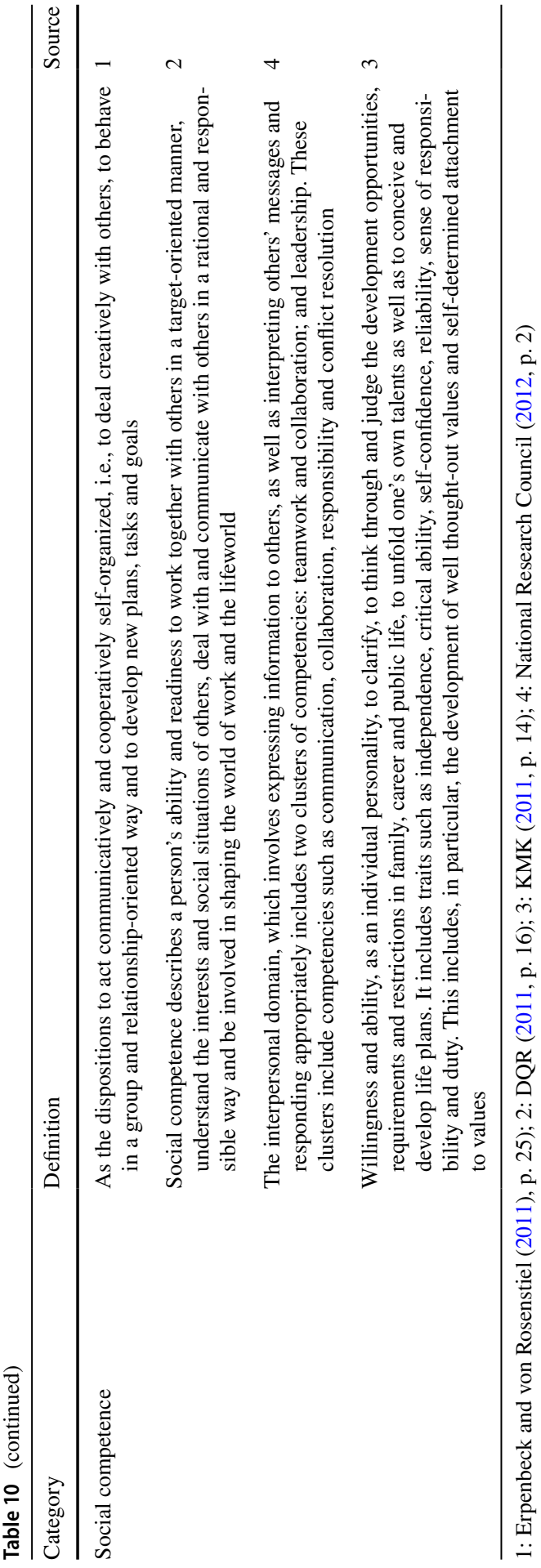


- Domain competence encompasses knowledge, skills and attitudes that constitute the disposition to process tasks in an autonomous, professionally appropriate and methodical manner and to evaluate the result.

- Personal competence describes a person's disposition to develop further and to shape his or her own life autonomously and responsibly within the particular social, cultural or occupational context.

- Social competence describes a person's disposition to work together with others in a target-oriented manner, understand the interests and social situations of others, deal with and communicate with others rationally and responsibly and be involved in shaping the world of work and the lifeworld.

\section{Clarification and organization of the concept entrepreneurial competence}

A clear definition of EC does not exist as agreed structure, and a shared understanding of the term is still missing in the literature (Komarkova et al. 2015). In the following chapter, we focus on the different components used by the authors and clarify their meanings and implications. For that reason, the definitions of Man et al. (2002), Bird (1995) and Mitchelmore and Rowley (2010) are presented and decomposed in Fig. 4. The components knowledge and skills are identical to the definitions we found in the conceptualizations of competence. However, in the entrepreneurial domain, we also find additional components such as traits, motives, self- images and social roles. We, therefore, clarify the terms and their relationship to each other to determine the core components and the specific characteristics of an EC.

Knowledge "Knowledge means the outcome of the assimilation of information through learning. Knowledge is the body of facts, principles, theories and practices that is related to a field of work or study. In the context of the EQF, there are two types of knowledge: theoretical and/or factual (EU 2017, p. 20).

From an educational perspective, prominent foundations of the knowledge concept were developed by Bloom (1956). In 2002 however, Krathwohl (2002) published an overview of an updated version of Bloom's Taxonomy of educational objectives (Bloom et al. 1984). This revised taxonomy attempts to correct some of the challenges with the original taxonomy. In his version, Krathwohl differentiates between the content of thinking (knowing what), and the procedures used in solving problems (knowing how). He introduced a new structure of knowledge dimensions with four, instead of three main types of knowledge (p. 214):

Factual knowledge The basic elements that students must know to be acquainted with a discipline or solve problems in it (Knowledge of terminology; Knowledge of specific details and elements).

Conceptual Knowledge The interrelationships among the basic elements within a larger structure that enable them to function together (Knowledge of classifications and categories; Knowledge of principles and generalizations; Knowledge of theories, models, and structures).

Procedural Knowledge How to do something; methods of inquiry, and criteria for using skills, algorithms, techniques, and methods (Knowledge of 


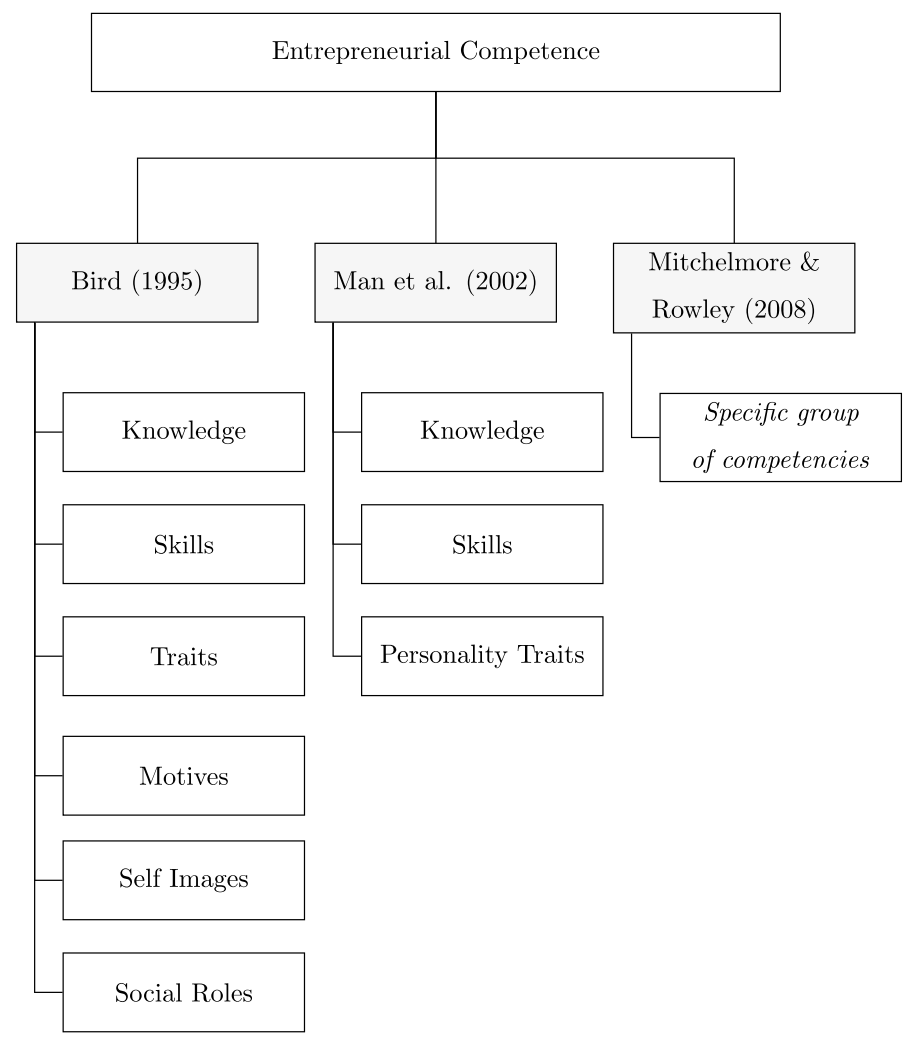

Fig. 4 Components of entrepreneurial competence

subject-specific skills and algorithms; Knowledge of subject-specific techniques and methods; Knowledge of criteria for determining when to use appropriate procedures).

Metacognitive Knowledge Knowledge of cognition in general as well as awareness and knowledge of one's own cognition (Strategic knowledge; Knowledge about cognitive tasks, including appropriate contextual and conditional knowledge; Self-knowledge).

Skills An individual needs a profound knowledge which is then applied in a given situation to solve problems and complete tasks. "Skills mean the ability to apply knowledge and use know-how to complete tasks and solve problems. (...) Skills are described as cognitive (involving the use of logical, intuitive and creative thinking) or practical (involving manual dexterity and the use of methods, materials, tools and instruments)" (EU 2017, p. 20). Moreover, the National Research Council (2012) describes skills as

knowledge that can be transferred in new situations. Transferable knowledge includes content knowledge in a domain and knowledge of how, why and when to apply this knowledge to answer questions and solve problems. This latter 
dimension of transferable knowledge-how, why and when to apply content knowledge-is often referred to in terms of "skill" (p. 2-2).

In other words, to complete tasks and solve problems in different situations, knowledge needs to be applied. Skill as a concept that transfers knowledge into action is, therefore, a crucial second component of competence.

Attitude "An attitude is a disposition to respond favorably or unfavorably to an object, person, institution or event (Ajzen 2005, p. 3)". Ajzen (2005) describes the term attitude as a "hypothetical construct" that is inaccessible to direct observation. However, attitudes allow positive or negative evaluations and therefore, can be measured through responses and or observations of human behavior (ibid). According to Ajzen, there are three categories of responses that go back to Plato: cognitive responses, affective responses and conative responses. Cognitive responses reflect perceptions of, and thoughts about, the attitude object. Affective responses on the other hand, can be described as feelings toward an object of attitude, while canative responses are described as action and behavior concerning the attitude object. In other words, attitudes determine a positive or negative effect on thoughts, feelings and actions. An unfavorable attitude toward an object or an event (i.e., becoming an entrepreneur) has a high negative impact on the behavior (performance) or decisions of the individual. In empirical educational research, performance is a critical requirement for demonstration, assessment and certification of an individual's competence. For that reason, we see attitude as the third component of competence.

Personality Trait "A personality trait is defined as a characteristic of an individual that exerts a pervasive influence on a broad range of trait-relevant responses" (Ajzen 2005, p. 2). According to Ajzen (2005), most social scientists agree on the evaluative nature of attitudes as they manifest themselves in a wide variety of observable responses (p. 3). In contrast to that personality traits describe response tendencies (i.e., to be sociable or self-confident) and are not necessarily evaluative (p. 6). While attitudes are viewed as more alterable and open to transformation, personality traits are assumed to be relatively stable over time. They focus on the individual him or herself, and they can thus be used to differentiate between individuals and to classify them in different personality types. The most prominent personality traits are defined by Goldberg (1990) as the "Big Five" factors:

1. Surgency (or extraversion),

2. Agreeableness,

3. Conscientiousness (or dependability),

4. Emotional stability (vs. neuroticism) and

5. Culture (or openness to experience)

Personality traits are viewed to be relatively stable and difficult to change. For that reason, they are not the best objective for development in entrepreneurial education settings. Personality traits are developed independently from education programs so that the person already possesses a specific set of traits and personal characteristics. They, of course, are a part of an entrepreneurial personality and can support learning and decision processes but in contrast to traits, knowledge, skills, and attitudes are 
the pedagogically recognized target objects to be developed and can be measured in academic settings. With this background, we do not include personality trait, as suggested by Bird (1995), is an integral component of an EC.

Self-image The concept of self-image is defined by Rosenberg (2015) as an attitude. "We conceive of the self-image as an attitude toward an object" (p. 5). It is congruent to the conceptualization of attitude by Ajzen (2005) and is therefore not an additional component of competence but an attitude toward him or herself.

Social Role "A social role is (...) defined as a set of expectations oriented toward people who occupy a certain position in a social system or group" (Gouldner 1957, p. 282). To get a clear understanding of the concept of social role, the concept of social status needs to be considered first. Social status is "a position in a particular pattern which is a collection of rights and duties" (Linton 1936, p. 113). Therefore, as stated by Gouldner (1957), a social role is considered to be a set of expectations toward people in a specific social position or status. The individual and society reinforce expectations, rights, duties and responsibilities that are connected to a social role and help people to find orientation and define an expected behavior in different situations. A social role, according to the underlying definition, is not an internal part of and is not controlled by the individual. A social role may indirectly contribute to the development of competence in a specific domain or even influence an attitude toward an object or an event. In this case, the expectations and duties (social roles) may have a direct effect on the three levels of attitude. As shown above, the concept of attitude is already an integral part of competence. In conclusion, the concept of social role is not an integral part of competence.

Motive A branch of psychology is motivational psychology. It deals with the research and explanation of purposeful human behavior and motivations, the "why" and "what for" that causes people to do or not do certain things. According to the McClelland, a motive (lat. Motus = motion, drive) is a "recurrent concern for a particular goal state, based on a natural incentive that energizes, orients and selects behavior" (McClelland 1985, p. 590). In other words, it is a reason for doing something. Thus, motives are considered to be components of self-control, as they enable the satisfaction of needs (Theilengerdes 2012, p. 19). The Theory of Needs, as proposed by McClelland (1985), states that human behavior is affected by three motivational factors - Need for Power, Need for Achievement, and Need for Affiliation. His studies indicate that there is a strong positive correlation between the need for achievement and performance. Moreover, he found that a country's economic development largely depends on the extent to which its citizens have the need for achievement (McClelland 1967).

(Murray, 1938, p. 80) states that "Actions which express what is commonly called ambition, will-to-power, desire for accomplishment and prestige have been classified as follows:

- Need for Superiority The need for achievement (will-to-power over things, people and ideas) and the need for recognition (efforts to gain approval and high social status).

- Need for Achievement To overcome obstacles, to exercise power, to strive to do something difficult as well and as quickly as possible (...). 
- Need for Recognition To excite praise and commendation; to demand respect; to boast and exhibit one's accomplishments; to seek distinction, social prestige, honors or high office."

Gartner (1985) recognized the need for achievement as an essential psychological characteristic of an entrepreneur. As described above, the concept of a motive is highly interconnected with our needs. A closer look at the theory of needs reveals that need for achievement, for instance, is a psychological characteristic and is in line with the definition of a personality trait by Ajzen (2005). Moreover, the research provided evidence that personality traits influence the realization of implicit motives (Hofer et al. 2015). Internal factors, such as personality traits and the individual structure of needs, as well as external factors (social norms and cultural characteristics), may result in different motives for behavior and performance. As described above, personality traits are relatively stable over time and challenging to change from outside. As external factors, culture and social norms are fix components and cannot be addressed for development in an academic setting so that the concept of a motive as suggested by Bird is not an integral part of an EC.

In 2015, the European Commission published a report on entrepreneurship competence that presents state-of-the-art identifying and comparing different theoretical and practical approaches from the academic and entrepreneurial world (see Komarkova et al. 2015). In order to define competence, the authors refer to the recommendation of the European Parliament (EU 2006) that defines competences as "knowledge, skills and attitudes" (p. 13). Another policy source is the OECD background paper by Lackeus (2015) who also found three basics components of a competence: "Entrepreneurial competencies are defined here as knowledge, skills and attitudes that affect the willingness and ability to perform the entrepreneurial job of new value creation" (p. 12).

Based on the discussion above, we consider an entrepreneurial competence as

the specific set of domain competences, social competences and personal competences needed to generate entrepreneurial action.

\section{Categories of entrepreneurial competence}

In "Results" section, we present categories of competence and entrepreneurial competence (Tables 5,8) identified in the literature. In addition to that in Table 8, we expanded our view and collected potential entrepreneurship-related categories to cover a wide variety of options as a basis for structuring and categorizing ECs. Based on the list of ECs identified in the literature, we critically examine the categories suggested by the authors and review their choices for classification.

The categorization approaches in Table 5 show different concepts in the entrepreneurship domain such as competence (Man et al. 2002), skills (Schallenkamp and Smith 2008), motive and traits (Bird 1995), domain field (Komarkova et al. 2015) and general terms (Bacigalupo et al. 2016). Moreover, in Table 9, we find processes and venture development phases (Moberg et al. 2014; Chell and Athayde 2009; Glasl and Lievegoed 1993), different areas as a framework for 
venture creation (Gartner 1985), and building blocks of a venture (Osterwalder and Pigneur 2010) as the distinctive elements. In particular, concerning ECs, we find a heterogeneous view on the classification of ECs. Furthermore, it is not clear how the authors developed the categories and which methods they used for classification.

Intuitively, a process-based classification would serve as a good overview and insight into a venture development process. A framework for venture development would be beneficial for students and other stakeholders. Unfortunately, the phases and processes are neither distinct and linear nor standardized for different projects, markets and products. Instead, the processes are interconnected and recurring. The lean start-up method by Ries (2011) suggest a cyclical and interactive approach to venture creation. In this case, the categories could not provide the criteria of exhaustiveness and mutually exclusives.

However, the venture creation processes take place on different levels and include various categories of competences. Based on the types given in Tables 5 , 8 and 7, three levels could be identified: (1) personal or individual level, (2) interpersonal or team level and (3) domain-specific expertise level. First, the entrepreneur and the team members need competences on a personal level such as acting proactively, process and understand complex information and recognize their limitation by reflection in their behavior, decisions and actions. Next, as they interact with the stakeholder inside and outside the company, they need social competences for communication, problem solving, upholding the spirit and the positive atmosphere within the team members and external partners. Finally, domain competences are needed to identify an opportunity, develop an organization and exploit the opportunity (3).

Based on the consolidated list of ECs in Table 7, we inductively developed a categorization framework and categories that similarly were introduced by Man et al. (2002). As a final result of the study, we adapt the categorizations to the requirements of the CFEC, consolidate the ECs from the literature review and suggest the list of ECs integrated into a framework for the CFEC. Considering the scope and aim of the study and the CFEC requirements, we transfer the general wording of the ECs into a competence-oriented version using the infinitive of suggested verbs. However, we excluded four items from the consolidated list: "Managerial competence" is a sub-category of a domain competence and can be classified in the "Strategic and Management" competence category. "Operational competences," on the other hand, cover the daily, hands-on individual efforts required to deliver results of given tasks. It is a sub-category of management competence and can be described as "Operation management." We did not find any specific competences in the literature that we could subsume to that category. It is also the case with "political" and "technical" competence, and therefore, we exclude the categories from our list. "Technical competence," however, is a particular category of domain competence. Undoubtedly, it is of vital importance for the creation of a specific type of new ventures, especially the new technology-based firms (NTBF) but no specific competence could be identified in our list that could be classified into this category (Fig. 5). 


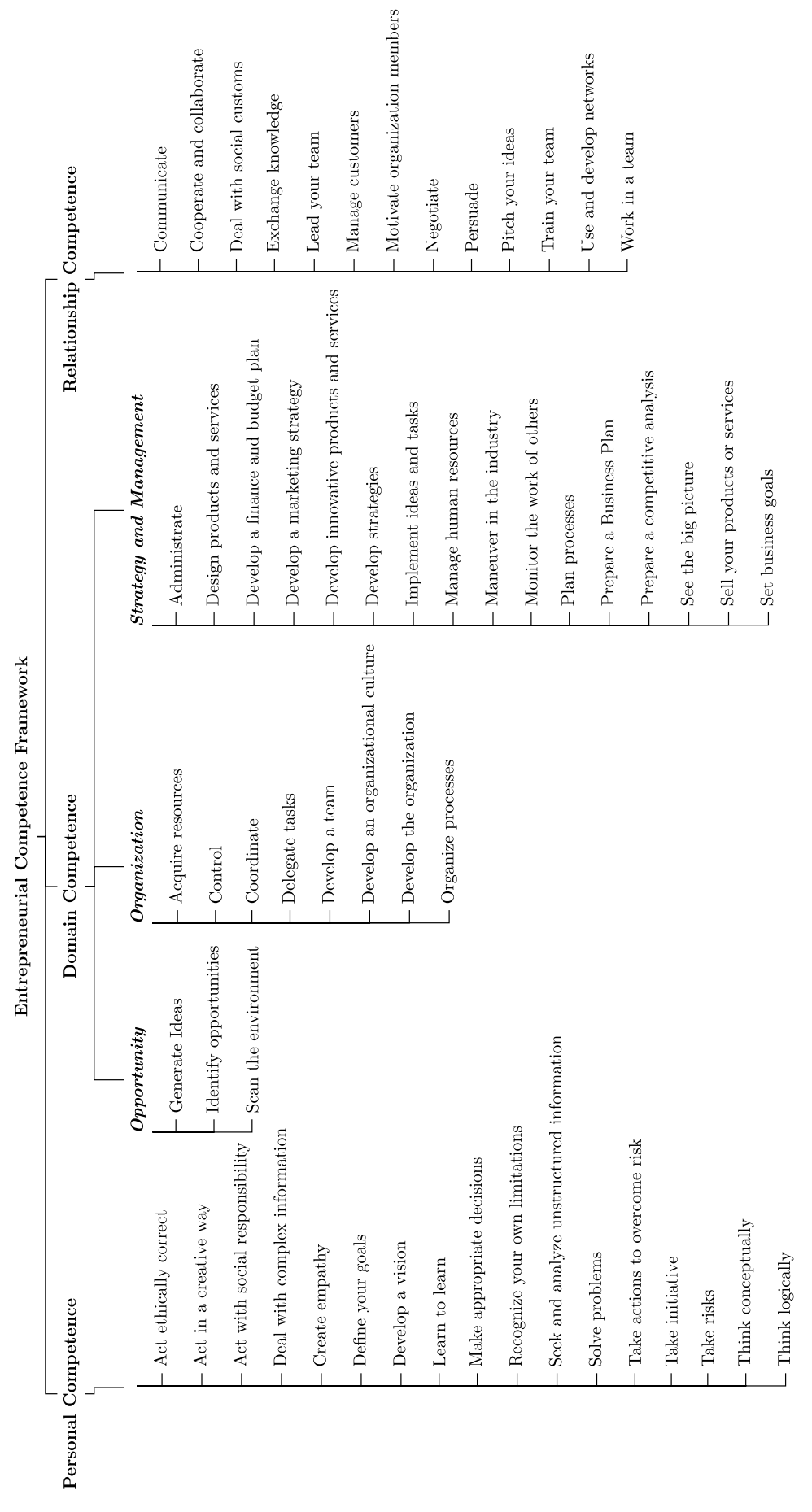

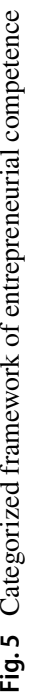




\section{Conclusions and limitations of the study}

The systematic literature review on entrepreneurial competences provided a comprehensive insight into the conceptualization and categorization of the terms "competence" and "entrepreneurial competence." We identified different approaches for the definition and categorization of both terms. As a result, we present a variety of perspectives and the potential applications of the concepts. Although many definitions of competence exist, they have in common that competence includes the essential elements-knowledge, skills, and attitudes- to solve problems in variable situations.

We conclude that domain competence, personal and social competence are appropriate categories for competence. In the domain of entrepreneurship, we identified the key authors on the definitions of EC, compiled their definitions, and present a consolidated list of ECs that we found in the lists of the authors. We apply the categorization approaches to the ECs in order to give educators assistance for the development of competence-oriented entrepreneurship courses. However, it cannot necessarily provide the answer to the question: What are the most decisive ECs?

As a suggestion for further research, we propose to further examine the variety of ECs and develop a scientifically sound and consolidated recommendation for vital ECs that should be developed in entrepreneurship classes. Moreover, we observe that knowledge, skills and attitudes as the fundamental components of competence are often used without a critical discussion and classification, and differentiation by the authors in the entrepreneurship domain. A clear understanding of the psychological concepts, such as traits, motives, and attitudes would help the scientific community, coaches and trainers as well as the entrepreneurs to create a clear understanding of necessary activities and the required competences for personal development, team formation, and the construction, conduction and assessment of education programs.

Based on the insights from the study, we developed a classification framework of ECs and suggested a consolidated list of ECs. The identified main categories are (1) domain competence, (2) personal competence and (3) relationship competence. For domain competence, we found three subcategories that characterize the entrepreneurship domain: opportunity recognition, organizational and strategic and management competence. It is evident, however, that not all of the mentioned competences can be developed in the entrepreneurship education settings. Many of the competences, especially the strategic and management competences, will be developed in a practical business environment or specific business administration degree programs. Entrepreneurship education and research is still a young discipline. The historical roots of its regional, contextual and functional development caused the heterogeneity in learning objectives, training methods and evaluation approaches as well as a great variety in definitions of key terms like entrepreneurship education and entrepreneurial competence. The purpose of the CEC is therefore not to define an exhaustive list ECs that should be taught in academic classes but to present an accurate inventory of ECs and their categories. It is a recommendation and an opportunity for future research to investigate and find a common understanding of the essence of ECs for entrepreneurship education. 
The study was performed according to the guidelines for systematic literature reviews by Kitchenham and Charters (2007). The systematic and unbiased identification of relevant research is of vital importance for the results and conceptualization of the topic. In fact, due to the search strategy and the application of the search string, we had to deal with a significant amount of potentially relevant publications. It cannot be excluded that some of the critical research was not recognized or not captured by the search strategy. In particular, concerning the limited period 2008-2018, it is possible that we missed essential insights from previous years of research. In this context, the list of ECs presented in Table 7 and in the final CEC framework may not be exhaustive. For instance, the key term "Business Model" is not indicated in our list. It is undoubtedly one of the critical ECs students need to prepare in entrepreneurial classes around the world as well as entrepreneurs need to develop to operate and acquire financial resources from investors.

\section{Acknowledgements Open Access funding provided by Projekt DEAL.}

Open Access This article is licensed under a Creative Commons Attribution 4.0 International License, which permits use, sharing, adaptation, distribution and reproduction in any medium or format, as long as you give appropriate credit to the original author(s) and the source, provide a link to the Creative Commons licence, and indicate if changes were made. The images or other third party material in this article are included in the article's Creative Commons licence, unless indicated otherwise in a credit line to the material. If material is not included in the article's Creative Commons licence and your intended use is not permitted by statutory regulation or exceeds the permitted use, you will need to obtain permission directly from the copyright holder. To view a copy of this licence, visit http://creativecommons.org/licen ses/by/4.0/.

\section{References}

Ahmad, N. H., Ramayah, T., Wilson, C., \& Kummerow, L. (2010). Is entrepreneurial competency and business success relationship contingent upon business environment? A study of malaysian smes. International Journal of Entrepreneurial Behaviour and Research, 16(3), 182-203.

Ahmad, N. H., Suseno, Y., Seet, P.-S., Susomrith, P., \& Rashid, Z. (2018). Entrepreneurial competencies and firm performance in emerging economies: A study of women entrepreneurs in malaysia. In V. Ratten, V. Braga, \& C. S. Marques (Eds.), Knowledge, learning and innovation: Research insights on cross-sector collaborations (pp. 5-26). Cham: Springer International Publishing.

Ajzen, I. (2005). Attitudes, personality, and behavior (Vol. 2). London: Open University Press.

Anis, S. N., Rasli, A. M., \& Hashim, N. H. (2016). Through the looking glass: Enhancing public university librarians' entrepreneurial competencies in facing the impact of globalization (conceptual paper). International Review of Management and Marketing, 6(4), 70-79.

Bacigalupo, M., Kampylis, P., Punie, Y., \& Van den Brande, G. (2016). EntreComp: The entrepreneurship competence framework. Luxembourg: Publication Office of the European Union, 10, 593884.

Bailey, K. D. (1994). Typologies and taxonomies: An introduction to classification techniques (Vol. 102). Thousand Oaks: Sage.

Barney, J. (1991). Firm resources and sustained competitive advantage. Journal of Management, 17(1), 99-120.

Barney, J. B. \& Arikan, A. M. (2001). The resource-based view: Origins and implications. In The Blackwell handbook of strategic management (pp. 124-188). Oxford: Blackwell Publishers.

Beaumont, G. (1995). Review of 100 NVQs and SVQs: A report submitted to the Department for Education and Employment. Evaluation Advisory Group.

BIBB (2018). Defintion of competence. Online. 
Bikse, V., \& Riemere, I. (2013). The development of entrepreneurial competences for students of mathematics and the science subjects: The latvian experience. Procedia-Social and Behavioral Sciences, $82,511-519$.

Bird, B. (1995). Towards a theory of entrepreneurial competency. Advances in Entrepreneurship, Firm Emergence and Growth, 2(1), 51-72.

Bloom, B. S., Engelhart, M. D., Furst, E. J., Hill, W. H., \& Krathwohl, D. R. (1984). Taxonomy of educational objectives: Handbook 1: Cognitive domain. Harlow: Longman Publishing Group.

Bloom, B. S., et al. (1956). Taxonomy of educational objectives: Cognitive domain (pp. 20-24). New York: McKay.

Bortkeviciene, V. (2015). The importance of entrepreneurial competence in activities. Holistinis Mokymasis, 2015(1), 81-91.

Bortkeviciene, V., \& Vaitkevicius, R. (2016). The development of adults' entrepreneurial competence for their successful career. International Journal of Learning and Intellectual Capital, 13(2-3), 238-249.

Boyatzis, R. E. (1982). The competent manager: A model for effective performance. New York: Wiley.

Bunk, G. (1994). Teaching competencein initial and continuing vocational trainingin the federal republicof germany. Vocational Training European Journal, 1, 8-14.

Chandler, G. N., \& Jansen, E. (1992). The founder's self-assessed competence and venture performance. Journal of Business Venturing, 7(3), 223-236.

Chell, E. \& Athayde, R. (2009). The identification and measurement of innovative characteristics of young people. Kingston university. Technical report, NESTA Research Report. July 2009, http:// eprints.kingston.ac.uk/5985/2....

Deist, F. D. L., \& Winterton, J. (2005). What is competence? Human Resource Development International, 8(1), 27-46.

DeSeCo. (2001). Definition and selection of competencies: Theoretical and conceptual foundations. Technical report, National Agency for Education National Agency for Education National Agency for Educaiton.

Dominique Simone Rychen, L. S. (2002). DeSeCo SYMPOSIUM - DISCUSSION PAPER. Swiss Federal Statistical Office.

DQR, A. (2011). The german qualifications framework for lifelong learning. Retrieved in November.

Edwards-Schachter, M., García-Granero, A., Sánchez-Barrioluengo, M., Quesada-Pineda, H., \& Amara, N. (2015). Disentangling competences: Interrelationships on creativity, innovation and entrepreneurship. Thinking Skills and Creativity, 16, 27-39.

ERIC. (2019). Comptence. Thesaurus online. Keyword: Competence.

Erkkilä, K. (2000). Entrepreneurial education: Mapping the debates in the United States, the United Kingdom and Finland. Milton Park: Taylor \& Francis.

Erpenbeck, J., \& Von Rosenstiel, L. (2011). Handbuch Kompetenzmessung: Erkennen, verstehen und bewerten von Kompetenzen in der betrieblichen, pädagogischen und psychologischen Praxis. Schäffer-Poeschel Verlag für Wirtschaft Steuern Recht.

EU. (2005). Towards a European qualifications framework for lifelong learning. Brussels: Council of the European Union.

EU. (2006). Recommendation of the European parliament and the council of 18 December 2006 on key competencies for lifelong learning. (2006/962/EC) 12, European Parliament.

EU. (2017). Council recommendation of 22 may 2017 on the european qualifications framework for lifelong learning and repealing the recommendation of the European parliament and of the council of 23 April 2008 on the establishment of the European qualifications framework for lifelong learning. Technical report, European Commission.

Garavan, T. N., \& Cinneide, B. O. (1994). Entrepreneurship education and training programmes: A review and evaluation-part 1. Journal of European Industrial Training, 18(8), 3-12.

Gartner, W. B. (1985). A conceptual framework for describing the phenomenon of new venture creation. Academy of Management Review, 10(4), 696-706.

Gartner, W. B., \& Vesper, K. H. (1994). Experiments in entrepreneurship education: Successes and failures. Journal of Business Venturing, 9(3), 179-187.

Glasl, F., \& Lievegoed, B. C. (1993). Dynamische Unternehmensentwicklung: Wie Pionierbetriebe und Bürokratien zu schlanken Unternehmen werden. Haupt Wien.

Goldberg, L. R. (1990). An alternative" description of personality": The big-five factor structure. Journal of Personality and Social Psychology, 59(6), 1216. 
Gouldner, A. W. (1957). Cosmopolitans and locals: Toward an analysis of latent social roles. i. Administrative Science Quarterly, 2(3), 281-306.

Gümüsay, A. A., \& Bohné, T. M. (2018). Individual and organizational inhibitors to the development of entrepreneurial competencies in universities. Research Policy, 47(2), 363-378.

Hayton, J. C., \& Kelley, D. J. (2006). A competency-based framework for promoting corporate entrepreneurship. Human Resource Management: Published in Cooperation with the School of Business Administration, The University of Michigan and in alliance with the Society of Human Resources Management, 45(3), 407-427.

Hofer, J., Busch, H., \& Schneider, C. (2015). The effect of motive-trait interaction on satisfaction of the implicit need for affiliation among german and cameroonian adults. Journal of Personality, 83(2), $167-178$.

Ismail, V. Y. (2014). The comparison of entrepreneurial competency in woman micro-, small-, and medium-scale entrepreneurs. Procedia-Social and Behavioral Sciences, 115, 175-187.

Ismail, V. Y., \& Zain, E. (2015). The portrait of entrepreneurial competence on student entrepreneurs. Procedia-Social and Behavioral Sciences, 169, 178-188.

Jamin, A., Akhuan, N. M., \& Zamri, M. T. (2016). The roles of entrepreneurial competencies and organizational innovation on business performance in service sectors smes. In Heritage, Culture and Society: Research agenda and best practices in the hospitality and tourism industry-proceedings of the 3 rd international hospitality and tourism conference, IHTC 2016 and 2 nd international seminar on tourism, ISOT 2016 (pp. 191-196). Taylor \& Francis.

Jones, C., \& English, J. (2004). A contemporary approach to entrepreneurship education. Education + Training, 46(8/9), 416-423.

Mohammed, K., Ibrahim, H. I., \& Shah, K. A. M. (2017). Empirical evidence of entrepreneurial competencies and firm performance: A study of woman entrepreneurs of Nigeria. Berlin: De Gruyter Open.

Katz, J. A. (2003). The chronology and intellectual trajectory of american entrepreneurship education: 1876-1999. Journal of Business Venturing, 18(2), 283-300.

Khalid, S., \& Bhatti, K. (2015). Entrepreneurial competence in managing partnerships and partnership knowledge exchange: Impact on performance differences in export expansion stages. Journal of World Business, 50(3), 598-608.

Kitchenham, B. (2007). Guidelines for performing systematic literature reviews in software engineering. Version 2.3, School of Computer Science and Mathematics Keele University Keele, Staffs ST5 $5 \mathrm{BG}, \mathrm{UK}$.

Kitchenham, B., \& Charters, S. (2007). Guidelines for performing systematic literature reviews in software engineering.

Klieme, E., \& Leutner, D. (2006). Kompetenzmodelle zur erfassung individueller lernergebnisse und zur bilanzierung von bildungsprozessen. Zeitschrift für Pädagogik, 52(6), 876-903.

KMK. (2011). Handreichung für die erarbeitung von rahmenlehrplänen der kultusministerkonferenz für den berufsbezogenen unterricht in der berufsschule und ihre abstimmung mit ausbildungsordnungen des bundes für anerkannte ausbildungsberufe.

Komarkova, I., Gagliardi, D., Conrads, J., \& Collado, A. (2015). Entrepreneurship competence: An overview of existing concepts, policies and initiatives. final report. Technical report, Joint Research Centre (Seville site).

Krathwohl, D. R. (2002). A revision of bloom's taxonomy: An overview. Theory Into Practice, 41(4), 212-218.

Kuratko, D. F. (2005). The emergence of entrepreneurship education: Development, trends, and challenges. Entrepreneurship Theory and Practice, 29(5), 577-597.

Kyndt, E., \& Baert, H. (2015). Entrepreneurial competencies: Assessment and predictive value for entrepreneurship. Journal of Vocational Behavior, 90, 13-25.

Lackeus, M. (2015). Entrepreneurship in education-What, why, when, how. entrepreneurship 360. background paper.

Linton, R. (1936). The study of man: an introduction. Appleton-Century.

Lokhoff, J., Wegewijs, B., Durkin, K., Wagenaar, R., Gonzalez, J., Isaacs, A. K., et al. (2010). A tuning guide to formulating degree programme profiles. Deusto: Publicaciones de la Universidad de Deusto.

Man, T. W. Y., Lau, T., \& Chan, K. F. (2002). The competitiveness of small and medium enterprises. A conceptualization with focus on entre preneurial competencies. Journal of Business Venturing, 17(2), 123-142. 
McClelland, D. C. (1967). Achieving society (Vol. 92051). New York: Simon and Schuster.

McClelland, D. C. (1973). Testing for competence rather than for "intelligence". American Psychologist, $28(1), 1$.

McClelland, D. C. (1985). How motives, skills, and values determine what people do. American Psychologist, 40(7), 812.

Mets, T., Kozlinska, I., \& Raudsaar, M. (2017). Patterns in entrepreneurial competences as the perceived learning outcomes of entrepreneurship education: The case of estonian heis. Industry and Higher Education, 31(1), 23-33.

Mitchelmore, S., \& Rowley, J. (2010). Entrepreneurial competencies: A literature review and development agenda. International Journal of Entrepreneurial Behavior and Research, 16(2), 92-111.

Mitchelmore, S., \& Rowley, J. (2013). Entrepreneurial competencies of women entrepreneurs pursuing business growth. Journal of Small Business and Enterprise Development, 20(1), 125-142.

Moberg, K., Vestergaard, L., Fayolle, A., Redford, D., Cooney, T., Singer, S., Sailer, K., \& Filip, D. (2014). How to assess and evaluate the influence of entrepreneurship education: A report of the astee project with a user guide to the tools. Technical report, The Danish Foundation for Entrepreneurship-Young Enterprise.

Mulder, M. (2002). Competentieontwikkeling in organisaties: Perspectieven en praktijk (competence development in organizations: Perspectives and practice). The Hague: Elsevier.

Mulder, M. (2007). Competence-the essence and use of the concept in icvt. European Journal of Vocational Training, 1(40), 5.

Mulder, M. (2014). Conceptions of professional competence. In S. Billett, C. Harteis, H. Gruber (Eds.), International handbook of research in professional and practice-based learning (pp. 107-137). Dordrecht: Springer.

Murray, H. A. (1938). Explorations in personality. Oxford: Oxford University Press.

Muzychenko, O. (2008). Competence-based approach to teaching international opportunity identification: Cross-cultural aspects. European Journal of International Management, 2(4), 418-436.

National Academies, T. (2012). Education for life and work: Developing transferable knowledge and skills in the 21st century. Technical report, National Research Council.

Osterwalder, A., \& Pigneur, Y. (2010). Business model generation: A handbook for visionaries, game changers, and challengers. New York: Wiley.

Peltonen, K. (2015). How can teachers' entrepreneurial competences be developed? A collaborative learning perspective. Education Training, 57(5), 492-511.

Penchev, P., \& Salopaju, A. (2011). Entrepreneurial competencies needed by managers in their work: Master thesis.

Phelan, C., \& Sharpley, R. (2012). Exploring entrepreneurial skills and competencies in farm tourism. Local Economy, 27(2), 103-118.

Prahalad, C. K., \& Hamel, G. (1990). The core competence of the corporation. Harvard Business Review, 68(3), 79-91.

Purzer, S., Fila, N., \& Nataraja, K. (2016). Evaluation of current assessment methods in engineering entrepreneurship education. Advances in Engineering Education, 5(1), n1.

Rasmussen, E., Mosey, S., \& Wright, M. (2011). The evolution of entrepreneurial competencies: A longitudinal study of university spin-off venture emergence. Journal of Management Studies, 48(6), 1314-1345.

Rasmussen, E., \& Wright, M. (2015). How can universities facilitate academic spin-offs? An entrepreneurial competency perspective. Journal of Technology Transfer, 40(5), 782-799.

RezaeiZadeh, M., Hogan, M., O'Reilly, J., Cunningham, J., \& Murphy, E. (2017). Core entrepreneurial competencies and their interdependencies: Insights from a study of irish and iranian entrepreneurs, university students and academics. International Entrepreneurship and Management Journal, 13(1), 35-73.

Ries, E. (2011). The lean startup: How today's entrepreneurs use continuous innovation to create radically successful businesses. Manhattan: Crown Books.

Rosenberg, M. (2015). Society and the adolescent self-image. Princeton: Princeton University Press.

Samwel Mwasalwiba, E. (2010). Entrepreneurship education: A review of its objectives, teaching methods, and impact indicators. Education Training, 52(1), 20-47.

Sánchez, J. (2012). The influence of entrepreneurial competencies on small firm performance. Revista Latinoamericana de Psicología, 44(2), 165-177.

Schaper, N., Reis, O., Wildt, J., Horvath, E., \& Bender, E. (2012). Fachgutachten zur kompetenzorientierung in studium und lehre. HRK projekt nexus (pp. 1-148). 
Schallenkamp, K., \& Smith, W. L. (2008). Entrepreneurial skills assessment: the perspective of SBDC directors. International Journal of Management and Enterprise Development, 5(1), 18-29.

Schelfhout, W., Bruggeman, K., \& de Maeyer, S. (2016). Evaluation of entrepreneurial competence through scaled behavioural indicators: Validation of an instrument. Studies in Educational Evaluation, 51, 29-41.

Schroder, H. M. (1989). Managerial competence: The key to excellence. Dubuque: Hunt Publishing Company.

Sentosa, S. U., Ariusni, A., \& Satrianto, A. (2017). Entrepreneurial competency development with training program for entrepreneur small scale industry sanjai crackers in bukittinggi city. International Journal of Economic Research, 14(17), 235-245.

Spencer, L. M. (1983). Soft skill competencies. Edinburgh: Scottish council for research. in education.

Sultana, R. G. (2009). Competence and competence frameworks in career guidance: Complex and contested concepts. International Journal for Educational and Vocational Guidance, 9(1), 15-30.

Tehseen, S., \& Ramayah, T. (2015). Entrepreneurial competencies and smes business success: The contingent role of external integration. Mediterranean Journal of Social Sciences, 6(1), 50.

Theilengerdes, R. (2012). Der Motivationskreislauf in non-profit-organisationen: Schlüsselfaktor für die Arbeit mit Haupt-und Ehrenamtlichen. Hamburg: Diplomica Verlag.

Trivedi, R. H., Savalia, J. R., \& Patel, J. D. (2009). Linking technopreneurial competence and education to business growth. International Journal of Technoentrepreneurship, 2(2), 168-185.

Vesper, K. H. (1990). New venture strategies. University of Illinois at Urbana-Champaign's Academy for entrepreneurial leadership historical research reference in entrepreneurship.

Weinert, F. E. (2001). Vergleichende leistungsmessung in schulen - eine umstrittene selbstverständlichkeit. In Weinert, F. E., editor, Leistungsmessungen in Schulen., pages 17-31. Beltz, Weinheim.

White, R. W. (1959). Motivation reconsidered: The concept of competence. Psychological Review, 66(5), 297.

Zarefard, M., \& Beri, S. E. C. (2017). Relationship between entrepreneurs' managerial competencies and innovative start-up intentionsin university students: An Iranian case. International Journal of Entrepreneurship, 21(3), 1-19.

Publisher's Note Springer Nature remains neutral with regard to jurisdictional claims in published maps and institutional affiliations. 